\title{
Evaluating sugarcane families by the method of Dynamic Technique for Order Preference by Similarity to Ideal Solution (DTOPSIS)
}

\author{
Peifang Zhao (1,2); James Todd (3); Jun Zhao (1,2); Jiayong Liu (1,2); Li Yao (1,2); Chaoxiang Hou (1,2); \\ Fenggang Zan $\left({ }^{1,2}\right)$; Hongming Xia $\left({ }^{1,2}\right)$; Kun Yang $\left({ }^{1,2}\right)$; Caiwen Wu $\left({ }^{1,2}\right)$; Xuekuan Chen $\left({ }^{1,2 *}\right)$ \\ (') Yunnan Sugarcane Research Institute, Yunnan Academy of Agricultural Sciences, No.363 east lingquan road, Kaiyuan, \\ Yunnan 661699, China. \\ (2) Yunnan Key Laboratory of Sugarcane Genetic Improvement, Kaiyuan, Yunnan Province 661699, P. R. China. \\ (3) USDA-ARS Sugarcane Field Station at Canal Point, Canal Point, Florida, United States. \\ $\left(^{*}\right)$ Corresponding author: chxk_ysri@163.com
}

Received: Apr. 22, 2014; Accepted: May 7, 2014

\begin{abstract}
Enlarging the quantity of seedlings of elite families and discarding inferior sugarcane (Saccharum spp.) families could improve sugarcane breeding and selection efficiency. The feasibility of using the method Dynamic Technique for Order Preference by Similarity to Ideal Solution (DTOPSIS) method was explored to identify superior sugarcane families. Data on 5 traits: Brix, millable stalks per stool (MS), stalk diameter (SD), plant height (PH), and percent pith were collected from two family trials having 17 families and two check cultivars at two sites including plant-cane and first-ratoon crops. The rest of the seedlings were planted into field for routine selection in the regular program. The DTOPSIS method calculates a comprehensive index $\left(C_{i}\right)$ which expresses the closeness of a solution to the ideal solution and was used in this study to test the distance of each family to the ideal family. The $C_{i}$ of the families was compared to the family selection rate in the regular program by determining the selection rate at Stage 1 to Stage 4 for each family in the regular program. The result indicated that the $C_{i}$ values calculated from family trials were significantly $(p<0.01)$ correlated to the selection rate at Stage $2(r=0.8059)$, Stage3 $(r=0.7967)$, and Stage 4 ( $r=0.8202)$, and indicating that promising clones were selected from families with higher $C_{i}$ values in the family trial. Thus, it could be feasible to use DTOPSIS to determine elite sugarcane families and to eliminate inferior families and thereby, increasing the variety selection efficiency.
\end{abstract}

Key words: Dynamic Technique for Order Preference by Similarity to Ideal Solution (DTOPSIS), family selection, Saccharum officinarum L.

\section{Análise de famílias de cana-de-açúcar pelo método Dynamic Technique for Order Preference by Similarity to Ideal Solution (DTOPSIS)}

\section{Resumo}

A elevação da quantidade de mudas de alta qualidade associada ao descarte das de baixa qualidade pode aprimorar os programas de seleção e melhoramento genético da cana-de-açúcar (Saccharum spp.). Este trabalho avaliou a capacidade do método Dynamic Technique for Order Preference by Similarity to Ideal Solution (DTOPSIS) de identificar famílias da cana-de-açúcar com elevada qualidade. As características avaliadas foram: Brix, aptidão para moagem, diâmetro do caule, altura e porcentagem de tecido parenquimatoso. Os dados foram coletados em dois experimentos com 17 famílias e duas cultivares incluindo cana soca e brota. O DTOPSIS estima o índice Ci que expressa a proximidade de uma solução particular à ideal. O Ci foi utilizado para avaliar a distância de cada família à família ideal. As demais mudas foram utilizadas em um programa tradicional de seleção. Os valores de Ci de cada família foram comparados às taxas de seleção de famílias obtidas pelo programa tradicional de seleção por meio da estimação das taxas de seleção nos estágios 1 a 4 . Os resultados indicaram que os valores de Ci calculados a partir dos experimentos foram significativamente correlacionados $(p<0,01)$ às taxas de seleção do estágio $2(r=0,8059)$, estágio 3 $(r=0,7967)$ e estágio $4(r=0,8202)$. Os resultados também indicaram que clones com promissor uso apresentam elevados valores de Ci. Conclui-se, portanto, que o método DTOPSIS é apropriado para selecionar e descartar mudas de alta e baixa qualidade, respectivamente, podendo elevar a eficiência dos programas de seleção.

Palavras-chave: Dynamic Technique for Order Preference by Similarity to Ideal Solution (DTOPSIS), seleção de famílias, Saccharum officinarum L. 


\section{INTRODUCTION}

Sugarcane (Saccharum officinarum L.) breeding starts with the hybridization of parental clones, followed by selection from a large population of seedlings. Even though large numbers of crosses have been used for producing seedlings for selection, the promising clones (assuming that the clones advanced to Stage 5 are promising clones) are only selected from several of these families. The families used for selection could be of great importance because poor families are a waste of time and funds (Tai and Miller, 1989) not only for the seedling stage but also for all subsequent stages of clonal selection. Thus, an effective method for selecting superior and discarding inferior families would help to improve the breeding efficiency, because selection of the best seedlings from the best families should increase the probability of selecting superior individuals in the later clonal selection stages (Kimbeng and Cox, 2003). Since the superiority of family selection was first identified by Hogarth (1971), it has been used in sugarcane breeding in Australia, India, Brazil, Columbia, Argentina, Indonesia, Cuba, South Africa, and the United States of America (Stringer et al., 2011) and was adapted to mainland China in 2006 (Wu, 2007).

The superiority of a family is determined by a range of parameters according to the breeding aims. These parameters include Brix, the estimate of tons of cane per hectare (TCH), the tons of sugar per hectare (TSH), disease reactions and so on. In other words, the ranking of a set of families could be by multiple objectives or parameters, and breeders are unlikely to simply judge the superiority or inferiority by only one or two parameters. The Dynamic Technique for Order Preference by Similarity to Ideal Solution (DTOPSIS) method described Yao et al. (1994) was first used for evaluating rural economies by several parameters. In plant breeding, the ideal clone or ideal family is represented by the best value for each trait or parameter involved, and a comprehensive index $\left(C_{i}\right)$ is given by the DTOPSIS method to describe how close each evaluated clone or family is to the ideal. DTOPSIS has been widely used in evaluating other crops: tomato (Shen and Dai, 2005), silage corn (Chen and Ma, 2006), rice (Yan et al., 2008), tobacco (Li et al., 2012) and so on. In sugarcane, it was first adapted for evaluating chewing cane cultivars (Zhao et al., 2007), and then used for sugarcane clones (Ma et al., 2013; Yang et al., 2014; Yu et al., 2013; Zhao et al., 2008) and also for staling (post-harvest deterioration) resistance (Zhao et al., 2012).

The potential of a cross to produce elite progeny for a trait could be accurately predicted by the cross mean of that trait (Chang and Milligan, 1992), and there are several traits such as Brix, millable stalks per stool (MS), stalk diameter (SD), plant height $(\mathrm{PH})$, and percent pith which could be used to determine the superiority of sugarcane families. The objectives of this study were to determine the potential of the DTOPSIS method for the evaluation of sugarcane families by comparing the $C_{i}$ to the selection rate at later clonal selection stages. If DTOPSIS successfully predicts family quality, then it can be useful for evaluating sugarcane families based on the five traits measured.

\section{MATERIAL AND METHODS}

\section{Origin of parental clones and seedlings}

During October 2007 and February 2008, a total of 17 cross combinations from 32 parental clones (Table 1) were planned. The fuzz was produced by the Yacheng

Table 1. Sugarcane parental clones and their sources

\begin{tabular}{|c|c|c|c|}
\hline Parental clones & Source & Parental clones & Source \\
\hline Co1001 & Sugarcane Breeding Institute, Coimbatore & YTO0-236 & GSIRI ${ }^{\mathrm{c}}$ \\
\hline Co419 & Sugarcane Breeding Institute, Coimbatore & YT85-177 & GSIRI \\
\hline CP72-1210 & USDA ARS Sugarcane Field Station at Canal Point & YT93-159 & GSIRI \\
\hline CP84-1198 & USDA ARS ${ }^{\text {a Sugarcane Field Station at Canal Point }}$ & ZZ74-141 & GSIRI \\
\hline L75-20 & Louisiana State University Agricultural Center at St.Gabriel,LA & ZZ92-126 & GSIRI \\
\hline Q121 & BSES $^{\mathrm{b}}$ Limited & YC97-48 & GSIRI \\
\hline Q141 & BSES Limited & YR05-458 & $\mathrm{YSRI}^{\mathrm{d}}$ \\
\hline Q165 & BSES Limited & YR05-612 & YSRI \\
\hline ROC1 & Taiwan Sugar Research Institute & YR05-782 & YSRI \\
\hline ROC10 & Taiwan Sugar Research Institute & YR05-785 & YSRI \\
\hline ROC24 & Taiwan Sugar Research Institute & YR06-100 & YSRI \\
\hline ROC25 & Taiwan Sugar Research Institute & YR95-105 & YSRI \\
\hline ROC26 & Taiwan Sugar Research Institute & YR99-155 & YSRI \\
\hline RB45 & Unknown & YZ89-151 & YSRI \\
\hline GT73-167 & Sugarcane Research Institute, Guangxi Academy of Agricultural Sciences & YZ94-343 & YSRI \\
\hline NJ57-416 & Sichuan Sugarcane Industry Research Institute & YZ94-375 & YSRI \\
\hline
\end{tabular}

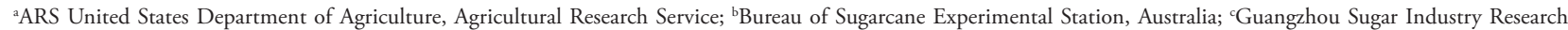

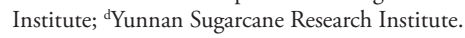


Sugarcane Breeding Station (YSBS) of Guangzhou Sugar Industry Research Institute (GSIRI), Hainan Province, and by the Ruili Sugarcane Breeding Station (RSBS) of YSRI, Yunnan Province (Table 2). The fuzz was received and sowed at the end of February 2008. For the seedling nursery, the temperature inside the greenhouse was kept within the 22 to $36{ }^{\circ} \mathrm{C}$ range. The leaves of seedlings were trimmed once a week after the age of 6-8 leaves. The seedlings of check cultivars ROC22 and ROC10 were obtained by planting single bud setts. Seedlings were then hardened for 15-20 days before transplanting them into the field.

\section{Field experimental designs}

Two identical family trials were conducted at two fields (E.103 ${ }^{\circ} 15^{\prime}, \mathrm{N} .23^{\circ} 42^{\prime}, 1050 \mathrm{~m}$ above sea level) at the beginning of May 2008 in a randomized complete block design (RCBD) with three replications for each trial, each containing seedlings derived from 17 families and two check cultivars (ROC22 and ROC10). The row length and row space was $6 \mathrm{~m}$ and $1.2 \mathrm{~m}$, respectively with 18 seedlings per family-plot. Seedlings within a row were planted $33 \mathrm{~cm}$ apart. The average values of each trait for each family or cultivar were used in the method of DTOPSIS to determine $C_{i}$ values. The regular selection stage was planted using the rest of seedlings (168-644 seedlings per family), and was used to determine the selection rate for each family for comparison to the $C_{i}$ value of each family.

The selection in the regular program of seedling stage was conducted in February 2009 when the seedlings were about 9 months old. The selection criterion was primarily the stool size based on visible assessment and pith. The Brix was not measured in the regular program. All stalks of each selected stool were planted in 1 to 2 rows for each un-replicated clone as Stage 2. The row length and spacing was $4.5 \mathrm{~m}$ and $1.2 \mathrm{~m}$, respectively. Selection within Stage 2 was conducted during February 2010 based on Brix (hand refractometer), plant height $(\mathrm{PH})$, stalk diameter (SD), pith, and disease incidence. The clones selected from Stage 2 were advanced to Stage 3 and planted in a Randomized
Complete Block Design (RCBD) with two replications in February 2010. The first replication was in a 1 row block for each clone, and the second was in 2-4 rows depending upon the amount of seed cane of each clone. The row length and spacing was $6 \mathrm{~m}$ and $1.2 \mathrm{~m}$, respectively (same as that in Stage 4). Selection in Stage 3 was done in February 2011 by comparing the superiority of the clones in plant height (measured from the ground surface to top visible dewlap from 10 plants), millable stalks (the number of stalks higher than $80 \mathrm{~cm}$ judged visually), stalk diameter (measured on the middle part of stalk from 10 plants), sugar content (Li et al., 2009) and disease with that of the check cultivars. The selected clones were advanced to Stage 4 in March 2011 by planting in a RCBD with two replications: $2-3$ rows for replication 1 and 2-5 rows for replication 2. Selection in Stage 4 was completed in February 2012 using the same criteria as in Stage 3. The selected clones were advanced to Stage 5 in February 2012.

Fertilizer was applied to entire field at an equivalent rate of $345 \mathrm{~kg} \mathrm{ha}^{-1} \mathrm{~N}, 144 \mathrm{~kg} \mathrm{ha}^{-1} \mathrm{P}$, and $90 \mathrm{~kg} \mathrm{ha}^{-1} \mathrm{~K}$ to both the plant cane and ratoon crops. Clear polyethylene mulch was added to cover the field to maintain soil temperature and moisture. It was removed after the beginning of the grand growth period.

\section{Data collection and analysis}

Plant height (PH, ground surface to top visible dewlap), number of millable stalks per stool (MS, $\mathrm{PH}>80 \mathrm{~cm}$, visual judgment), stalk diameter of primary stalk (SD, 5-6 internodes from the ground), and pith percentage (middle to top part of stem) data were recorded for plant and ratoon crops from family trials at the two fields. The plant cane was measured on 20-22 December 2008 and ratoon crops were measured on 18-22 December 2009. For each replication, ten seedlings were randomly chosen for each measurement. The average values of the two family trials at plant and ratoon crops for each trait $\left(Y_{i j}\right.$ in Table 3) were used as 5 parameters in the DTOPSIS method described by Yao et al. (1994) for calculating a comprehensive index $\left(C_{i}\right)$ for each family and

Table 2. The 17 sugarcane crosses and the crossing site, and their Identification number (ID No.) for DTOPSIS

\begin{tabular}{|c|c|c|c|c|c|}
\hline Crosses & ID No. & Crossing site & Crosses & ID No. & Crossing site \\
\hline ZZ92-126×L75-20 & 1 & 1 & RB45×YC97-48 & 11 & 1 \\
\hline YZ94-375×RB45 & 2 & 1 & ROC26×YR05-782 & 12 & 2 \\
\hline YZ94-343×ROC24 & 3 & 1 & ROC25×GT73-167 & 13 & 1 \\
\hline YR99-155×CP72-1210 & 4 & 1 & $\mathrm{ROC} 1 \times \mathrm{Co} 1001$ & 14 & 1 \\
\hline YR06-100×ROC10 & 5 & 2 & Q141×YR05-458 & 15 & 2 \\
\hline YR05-785×YTO0-236 & 6 & 2 & CP84-1198×ZZ74-141 & 16 & 1 \\
\hline YR05-612×Q165 & 7 & 2 & Co419×YR95-105 & 17 & 2 \\
\hline YT93-159×Q121 & 8 & 2 & ROC10 & 18 & check \\
\hline YT85-177×YZ89-151 & 9 & 1 & ROC22 & 19 & check \\
\hline NJ57-416×ROC10 & 10 & 1 & & & \\
\hline
\end{tabular}

Crossing site 1: Yacheng Sugarcane Breeding Station, Guangzhou Sugar Industry Research Institute, Yacheng, Hainan Province, China; Crossing site 2: Ruili Sugarcane Breeding Station, Yunnan Sugarcane Research Institute, Ruili, Yunnan Province, China. 
Table 3. The mean values $\left(Y_{i j}\right)$, and the ideal family for 5 evaluated traits from Sugarcane families and checks

\begin{tabular}{|c|c|c|c|c|c|}
\hline ID No. & Brix (\%) & MS(no. stalks) & $\mathrm{SD}(\mathrm{cm})$ & $\mathrm{PH}(\mathrm{cm})$ & Pith (\%) \\
\hline 1 & 19.58 & 3.57 & 2.68 & 172.93 & 40.00 \\
\hline 2 & 18.63 & 3.96 & 2.39 & 191.50 & 40.00 \\
\hline 3 & 18.58 & 3.35 & 2.37 & 153.89 & 18.33 \\
\hline 4 & 18.95 & 3.48 & 2.57 & 174.03 & 35.71 \\
\hline 5 & 19.42 & 3.49 & 2.40 & 173.77 & 41.67 \\
\hline 6 & 19.17 & 4.13 & 2.44 & 157.22 & 45.00 \\
\hline 7 & 19.93 & 3.68 & 2.29 & 184.00 & 45.00 \\
\hline 8 & 19.97 & 4.18 & 2.51 & 176.92 & 33.33 \\
\hline 9 & 19.18 & 2.79 & 2.26 & 160.30 & 45.00 \\
\hline 10 & 18.75 & 3.76 & 2.46 & 173.82 & 35.00 \\
\hline 11 & 20.04 & 3.20 & 2.48 & 169.39 & 55.00 \\
\hline 12 & 18.48 & 3.17 & 2.40 & 176.48 & 35.00 \\
\hline 13 & 19.52 & 3.81 & 2.56 & 183.87 & 38.33 \\
\hline 15 & 17.63 & 3.73 & 2.49 & 193.70 & 48.33 \\
\hline 16 & 19.71 & 2.73 & 2.30 & 178.45 & 40.00 \\
\hline 17 & 17.44 & 3.80 & 2.70 & 192.69 & 22.86 \\
\hline 18 & 19.41 & 3.02 & 2.57 & 164.83 & 32.14 \\
\hline 19 & 18.10 & 3.28 & 2.84 & 206.50 & 25.45 \\
\hline Idea family & 20.04 & 4.18 & 2.84 & 206.50 & 18.33 \\
\hline
\end{tabular}

MS, millbale stalks per stool; SD, stalk diameter; $\mathrm{PH}$, plant height.

two check cultivars ROC22 and ROC10. The calculation of $C_{i}$ value was processed in Microsoft office excel 2010. The selection rate (SR) for each stage was calculated by the number of selected clones $\times 100$ divided by the number of seedlings in the seedlings stage. They were SR1 for Stage 1, SR2 for Stage 2, SR3 for Stage 3 and SR4 for Stage 4. Spearman rank correlations of $C_{i}$ with SR1, SR2, SR3 and SR4 were processed in software StatistixV8 (Statistix, 2014).

In DTOPSIS, the parameters involved could be grouped as positive, neutral or negative depending upon the breeding aim. High values are favored for positive parameters, and neutral values for neutral parameters, and low values for negative parameters. In this study, Brix, MS, SD and PH were used as positive because they were Brix yield components, and pith was used as a negative because clones with pith may be linked to low juice rate. Some traits could be treated as neutral parameters when extremes of that trait are not favored. There was no neutral parameter in this study.

The $C_{i}$ was calculated as following:

Each of the five traits had different units, but $C_{i}$ is a comprehensive index that is calculated using all five traits. The data (Table 3 ) for each trait were transformed into the form of $Z_{i j}$ (Table 4) which was within the range of 0.000 to 1.000. The positive, the neutral and the negative parameters were transformed according to (1), (2) and (3) respectively.

$$
Z_{i j}=\left\{\begin{array}{l}
Y_{i j} / Y_{i} \max , \text { where } Y_{i} \max =\max \left(Y_{i j}\right) \\
Z_{i j}=Y_{j o} /\left[Y_{j o}+\text { abs }\left(Y_{j o}-Y_{i j}\right)\right] \\
Y_{i} \min / Y_{i j}, \text { where } Y_{i} \min =\min \left(Y_{i j}\right)
\end{array}\right.
$$

Where, ' $i$ ' means the number of families or check cultivars, $i=1,2,3, \sim 19$; $^{\prime} j$ is the number of traits, $j=1$ (Brix), 2 (MS), 3 (SD), 4 (PH), 5(Pith); $Y_{i j}$ means the values of the $i^{\text {th }}$ cross for the $j^{\text {th }}$ trait; for each trait, $Y_{j o}$ was the objective value if a neutral parameter like fiber content (Zhao et al., 2008) is involved and 'abs' is the absolute value. The result of calculation of $Z_{i j}$ is given at table 4 . Based on $Z_{i j}$, a decision matrix $R_{i j}$ could be calculated by multiplying each $Z_{i j}$ to weight coefficient $\left(W_{j}\right)$ which is set by the breeders according to their breeding aims. According to our breeding aims, the present study gave 0.60 of the weight coefficient to the cane yield components MS(0.25), SD (0.25) and PH (0.10), and another 0.40 was given to Brix (0.30) and pith (0.10). $W_{j}=\{0.30,0.25,0.25,0.10,0.10\}$ for Brix, MS, SD, PH and Pith, respectively (Table 4$),\left(W_{j} \in(0,1), \sum_{j=1}^{5} W_{j}=1\right)$. The decision matrix of $R_{i j}$ is calculated by formula (4)

$R_{i j}=W_{i j} \times Z_{i j}$

In the $R_{i j}$ matrix (Table 5), the highest value $X_{j}^{+}$for each trait was found by (5)

$X_{j}^{+}=\max _{i}\left(R_{i j}\right)$

They were $X_{j}^{+} \cdot\{0.3000,0.2500,0.2500,0.1000,0.1000\}$; the lowest value $X_{j}^{-}$for each trait was found by (6),

$X_{j}^{-}=\min _{i}\left(R_{i j}\right)$

They were $X_{j}^{-} \cdot\{0.2612,0.1629,0.1992,0.0745,0.0333\}$. Based on the $X_{j}^{+}$and $X_{j}^{-}$, and $R_{i j}$, the negative Euclidean distance $S_{j}^{+}$and positive Euclidean distance $S_{j}^{-}$were calculated by (7) and (8), respectively. 
$S_{i}^{+}=\sqrt{\sum_{j=1}^{19}\left(R_{i j}-X_{j}^{+}\right)^{2}}$, where $X_{j}^{+}=\left(X_{1}^{+}, X_{2}^{+}, X_{3}^{+}, X_{4}^{+}, X_{5}^{+}\right)$

$S_{i}^{-}=\sqrt{\sum_{j=1}^{19}\left(R_{i j}-X_{j}^{-}\right)^{2}}$, where $X_{j}^{-}=\left(X_{1}^{-}, X_{2}^{-}, X_{3}^{-}, X_{4}^{-}, X_{5}^{-}\right)$

The $C_{i}$ (Table 6) is calculated by

$C_{i}=S_{i}^{-} /\left(S_{i}^{-}+S_{i}^{+}\right), C_{i} \in(0,1)$

The higher the $C_{i}$ is, the closer the family is to the ideal family.

Table 4.The standardized transformed values $\left(Z_{i j}\right)^{\text {ab }}$ of five traits from 17 sugarcane families and two check cultivars, and the weight coefficient $\left(W_{j}\right)$

\begin{tabular}{|c|lllll|}
\hline ID No. & Brix $^{\mathbf{a}}$ & MS $^{\mathbf{a}}$ & SD $^{\mathbf{a}}$ & PH $^{\mathbf{a}}$ & Pith $^{\mathbf{b}}$ \\
\hline 1 & 0.9771 & 0.8532 & 0.9435 & 0.8374 & 0.4583 \\
\hline 2 & 0.9295 & 0.9467 & 0.8401 & 0.9274 & 0.4583 \\
\hline 3 & 0.9270 & 0.7996 & 0.8347 & 0.7452 & 1.0000 \\
\hline 4 & 0.9458 & 0.8309 & 0.9067 & 0.8428 & 0.5133 \\
\hline 5 & 0.9691 & 0.8352 & 0.8459 & 0.8415 & 0.4400 \\
\hline 6 & 0.9566 & 0.9863 & 0.8599 & 0.7613 & 0.4074 \\
\hline 7 & 0.9945 & 0.8796 & 0.8054 & 0.8910 & 0.4074 \\
\hline 8 & 0.9967 & 1.0000 & 0.8853 & 0.8567 & 0.5500 \\
\hline 9 & 0.9570 & 0.6662 & 0.7966 & 0.7763 & 0.4074 \\
\hline 10 & 0.9359 & 0.8976 & 0.8665 & 0.8417 & 0.5238 \\
\hline 11 & 1.0000 & 0.7654 & 0.8723 & 0.8203 & 0.3333 \\
\hline 12 & 0.9220 & 0.7579 & 0.8442 & 0.8546 & 0.5238 \\
\hline 14 & 0.9741 & 0.9097 & 0.9005 & 0.8904 & 0.4783 \\
\hline 15 & 0.9696 & 0.7894 & 0.8671 & 0.9245 & 0.5238 \\
\hline 16 & 0.8799 & 0.8922 & 0.8770 & 0.9380 & 0.3793 \\
\hline 17 & 0.9836 & 0.6516 & 0.8089 & 0.8642 & 0.4583 \\
\hline 19 & 0.8705 & 0.9080 & 0.9510 & 0.9331 & 0.8021 \\
\hline W & 0.9687 & 0.7216 & 0.9036 & 0.7982 & 0.5704 \\
\hline
\end{tabular}

MS, millbale stalks per stool; SD, stalk diameter; PH, plant height; ${ }^{a}$ Equals the family and check mean divided by the highest value within the family or check varieties; ${ }^{b} \mathrm{Equals}$ the least value within 17 families and two checks divided by each mean of a family or a check.

Table 5.The decision matrix $\left(R_{i j}\right)^{a}$ from five traits of 17 families of Sugarcane and two check cultivars

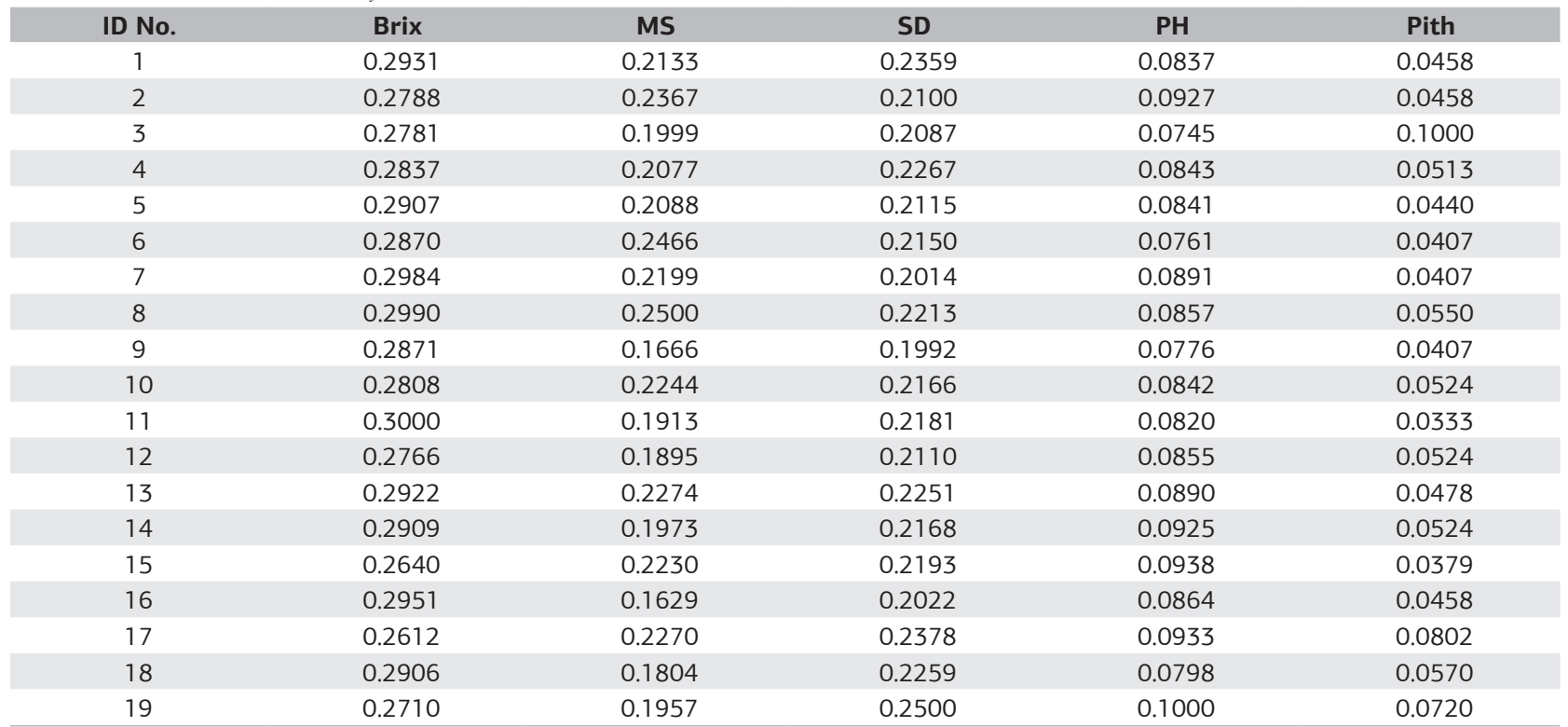

MS, millbale stalks per stool; SD, stalk diameter; $\mathrm{PH}$, plant height; ${ }^{a} R_{i j}$ was calculated by standardized transformed values $\left(Z_{i j}\right)$ multiplied by the weight coefficient $W_{j}$. 
Table 6. The positive Euclidean distance $\left(S_{j}^{+}\right)$, negative Euclidean distance $\left(S_{j}^{-}\right)$, and comprehensive index $\left(C_{i}\right)$ for each family or check cultivars

\begin{tabular}{|cclcc|}
\hline ID No. & $S_{j}^{+}$ & $S_{j}^{-}$ & $C_{i}$ & Rank of $C_{i}$ \\
\hline 8 & 0.0553 & 0.1005 & 0.6452 & 1 \\
\hline 17 & 0.0512 & 0.0903 & 0.6380 & 2 \\
\hline 13 & 0.0635 & 0.0789 & 0.5541 & 4 \\
\hline 6 & 0.0741 & 0.0893 & 0.5466 & 5 \\
\hline 19 & 0.0676 & 0.0769 & 0.5321 & 6 \\
\hline 2 & 0.0722 & 0.0798 & 0.5249 & 7 \\
\hline 3 & 0.0731 & 0.0787 & 0.5184 & 8 \\
\hline 1 & 0.0692 & 0.0718 & 0.5090 & 10 \\
\hline 1 & 0.0683 & 0.0702 & 0.5070 & 11 \\
\hline 15 & 0.0831 & 0.0700 & 0.4573 & 12 \\
\hline 14 & 0.0722 & 0.0608 & 0.4572 & 13 \\
\hline 11 & 0.0828 & 0.0665 & 0.4453 & 14 \\
\hline 12 & 0.0816 & 0.0578 & 0.4147 & 15 \\
\hline 9 & 0.0793 & 0.0554 & 0.4112 & 16 \\
\hline
\end{tabular}

according to how important each trait is for their breeding aims. In the present study, weight coefficients of $0.30,25$, $0.25,0.10$ and 0.10 were given to traits Brix, MS, SD, PH and pith, respectively (Table 4). A high-yielding commercial variety requires satisfactory stalk number, stalk diameter, and stalk length (Chang and Milligan, 1992). Stalk number is the most important component of cane yield (James, 1971; Milligan et al., 1990) and stalk diameter is a reliable trait for selection at seedling stage (James and Miller, 1971; Tai and Miller, 1989) and it is also important for hand harvesting practiced by farmers in some sugarcane regions. Because the crop was short on average (Table 3), the selection emphasized number of millable stalks and stalk diameter rather than plant height at seedling stage. Brix is highly associated with sugar content (Papini-Terzi et al., 2008), which is one of the most important sugarcane breeding aims. Improvement of sugar content is believed to be more beneficial than improvement of cane yield (Jackson, 2005); moreover, the selection for sugar content was found to be more accurate than other traits for cane yield within small plots (Jackson and McRae, 2001). The Brix was given a high weight coefficient even if it was not measured during the selection in seedling stage because the measurement of Brix is laborious and expensive; however, it was measured on clones judged superior to the check cultivars by visible or yield comparison at later selection stages. During the seedling stage selection, the pith was checked and some the seedlings judged as vigorous were selected even though they showed a slight amount of pith, and would be discarded at the later stages if the pith exists and lowered the juice percentage when compared to check cultivars.
The principle purpose of DTOPSIS is to determine how close the evaluated subject (e.g. a sugarcane family) is to the ideal solution (e.g. the ideal family in Table 3) (Yao et al., 1994). Among all the 17 families and two check cultivars, the families with the highest Brix and the largest MS were found in crosses RB45×YC97-48 (20.04\%) and YT93-159×Q121 (4.18 stalks), respectively. The largest SD $(2.84 \mathrm{~cm})$ and $\mathrm{PH}(206.50 \mathrm{~cm})$ were found in the check cultivar ROC22, and the lowest pith was found in cross YZ94-343×ROC24 (18.33\%). So, the ideal family for this study was characterized with Brix, MS, SD, PH and pith of $20.04 \%, 4.18$ (stalks per stool), $2.84 \mathrm{~cm}, 206.50 \mathrm{~cm}$ and $18.33 \%$, respectively. The $C_{i}$ ranged from 0.1896 to 0.6452 (Table 7) and described how close each family was to the ideal family comprehensively. There were four families YT93-159×Q121, Co419×YR95-105, ROC25×GT73-167, YR05-785 $\times$ YT00-236 that showed higher $C_{i}$ values than ROC22 $\left(C_{i}=0.5321\right)$. These four families also had clones advanced to Stage 5 . There were nine families that showed $C_{i}$ values between two check cultivars, and two of them had clones advanced to Stage 5 . For the four families with $C_{i}$ values lower than those of the two check cultivars, no clones were selected. Of the seven families that had higher $C_{i}$ values than 0.5000, six of them have clones selected in Stage 4.

\section{The SR and correlations with $C_{i}$ values}

For each cross evaluated in the family trials, at least 168 seedlings were planted for selection in Stage 1 (Table 7). The selection rate at Stage 1 (SR1) varied from 1.71 to $6.52 \%$, with an overall selection rate of $3.50 \%$ for Stage 1 . 
Table 7. The selection rate (SR) at Stage $1(\mathrm{SR} 1)$, Stage 2(SR2), Stage 3(SR3), and Stage 4(SR4), and the comprehensive index $\left(C_{i}\right)$ value of 17 sugarcane families and two check cultivars

\begin{tabular}{|c|c|c|c|c|c|c|c|}
\hline ID No. & NS & SR1 & SR2 & SR3 & SR4 & Stage ${ }^{a}$ & $C_{i}$ \\
\hline 8 & 182 & 3.30 & 2.75 & 1.65 & 1.65 & 5 & 0.6452 \\
\hline 17 & 644 & 6.52 & 1.55 & 0.47 & 0.31 & 5 & 0.6380 \\
\hline 13 & 210 & 6.19 & 1.90 & 1.43 & 0.48 & 5 & 0.5541 \\
\hline 6 & 252 & 3.17 & 0.79 & 0.40 & 0.40 & 5 & 0.5466 \\
\hline 19 & I & I & l & l & I & I & 0.5321 \\
\hline 2 & 280 & 4.64 & 1.07 & 0.36 & 0.36 & 5 & 0.5249 \\
\hline 3 & 392 & 4.85 & 0.26 & 0.00 & 0.00 & 3 & 0.5184 \\
\hline 1 & 630 & 5.24 & 1.75 & 0.63 & 0.16 & 5 & 0.5090 \\
\hline 10 & 602 & 1.66 & 0.33 & 0.00 & 0.00 & 3 & 0.5070 \\
\hline 7 & 252 & 5.16 & 0.00 & 0.00 & 0.00 & 2 & 0.4573 \\
\hline 4 & 574 & 1.92 & 0.17 & 0.00 & 0.00 & 3 & 0.4572 \\
\hline 15 & 518 & 1.93 & 0.19 & 0.00 & 0.00 & 3 & 0.4453 \\
\hline 5 & 308 & 1.62 & 0.00 & 0.00 & 0.00 & 2 & 0.4147 \\
\hline 14 & 616 & 3.41 & 0.00 & 0.00 & 0.00 & 2 & 0.4112 \\
\hline 18 & I & I & I & I & I & I & 0.3610 \\
\hline 11 & 392 & 1.79 & 0.00 & 0.00 & 0.00 & 2 & 0.3524 \\
\hline 12 & 168 & 2.98 & 0.00 & 0.00 & 0.00 & 2 & 0.3042 \\
\hline 16 & 238 & 3.36 & 0.42 & 0.00 & 0.00 & 3 & 0.2508 \\
\hline 9 & 350 & 1.71 & 0.00 & 0.00 & 0.00 & 2 & 0.1896 \\
\hline$r$ & I & 0.4507 & $0.7967^{* *}$ & $0.8059 * *$ & $0.8202^{* *}$ & I & I \\
\hline
\end{tabular}

NS, the number of seedlings planted in seedling Stage for selection; ${ }^{*}$ the correlations of SR with $C_{i}$ was significant at $\mathrm{P}=0.01 . r$ Spearman correlation coefficient; athe final stage to which clones were advanced from each family.

In Stage 2, the SR2 ranged from 0.00 to $2.75 \%$, and no clones were selected from 6 families. In Stage 3, the SR3 ranged from 0.00 to $1.65 \%$, and no clone was selected from 11 families. In Stage 4, the SR4 ranged from 0.00 to $1.65 \%$, and no clone was selected from 11 families. Judging from the clones advanced to Stage 5 that were selected from six families, around 64\% (11 families out of 17) should not have been planted as seedlings for selection. During individual selection, if one family is superior to the check in one character but not in others, it can result in a lower selection rate (Wells and Kofoid, 1986). The low selection rate for YR06-100×ROC10 (1.62\%) may be the result of a comparatively small stalk diameter and high pith percentage, even its mean Brix was comparatively high; however, the Brix was not measured during the selection at seedlings stage. Six families YT93-159×Q121, ROC25×GT73-167, YR05785×YT00-236, YZ94-375×RB45, Co419×YR95-105 and ZZ92-126 $\times$ L75-20 should be considered for use in selection.

The $C_{i}$ values were significantly $(\mathrm{P}<0.01)$ correlated withSR2, SR3 and SR4 (Table 7). It showed a positive correlation $(r=0.4507)$ with the SR1 but was not significant which could be the result of not measuring the Brix during seedling selection. If clones that have been advanced to Stage 5 (reflect by SR4>0.00) are considered as promising clones, then all 6 families showed higher $C_{i}$ values than 0.5000 , and 4 of them had higher $C_{i}$ values than ROC22. In contrast, all the families with lower $C_{i}$ values than both check cultivars had $0.00 \%$ of the SR3 and SR4, and three of them had no clones selected after Stage 2. This suggested that there was a higher possibility for selecting promising clones from families with higher $C_{i}$ values.

\section{CONCLUSION}

Evaluating sugarcane families is multi-objective process, because the superiority of a familyis composed of several traits. In this study, sugarcane families were evaluated based on five parameters, namely Brix, plant height, number of millable stalks per stool, stalk diameter and pith percentage at family trial. The $C_{i}$ values calculated by the DTOPSIS method for family trials were significantly correlated with the selection rate at Stages 2, 3 and 4. The DTOPSIS method can be used in sugarcane family evaluation based on data collected from family trials and the weight coefficient set by the breeder. The $C_{i}$ values and selection rate indicated six families (YT93159×Q121, Co419×YR95-105, ROC25×GT73-167, YR05785×YT00-236, YZ94-375×RB45 and ZZ92-126×L75-20) could be considered for further selection.

\section{ACKNOWLEDGEMENTS}

This study was supported by the Earmarked Fund for China Agriculture Research System (CARS-20-1-1), the Earmarked Fund for Yunnan Province Agriculture Research System, and Yunnan Provincial fund for exploiting key 
products (2012BB014). The authors are grateful to the prereview and language correction by Dr. Jack. C. Comstock (Plant pathologist) and Dr. Serge J. Edme (Research geneticist) of USDA -ARS Sugarcane Field Station at Canal Point, FL.

\section{REFERENCES}

CHANG, Y.S.; MILLIGAN, S.B. Estimating the potential of sugarcane families to produce elite genotypes using univariate cross prediction method. Theoretical and Applied Genetics, v.84, p.662-671, 1992. PMid:24201355.

CHEN, F.J.; MA, C.L. Evaluation on silage new corn cultivar by DTOPSIS analytical method. Journal of Hebei Agriculture Sciences, v.10, p.48-51, 2006.

HOGARTH, D.M. Quantitative inheritance studies in sugarcane II. Correlations and predicted responses to selection. Australian Journal of Agricultural Research, v.22, p.103-109, 1971. http://dx.doi. org/10.1071/AR9710103

JACKSON, P. Breeding for improved sugar content in sugarcane. Field Crops Research, v.92, p.277-290, 2005. http://dx.doi.org/10.1016/j. fcr.2005.01.024

JACKSON, P.; MCRAE, T.A. Selection of sugarcane clones in small plots: effect of plot size and selection criterion. Crop Science, v.41, p.315-322, 2001. http://dx.doi.org/10.2135/cropsci2001.412315x

JAMES, N.J. Yield components in random and selected sugarcane populations. Crop Science, v.11, p.906-908, 1971. http://dx.doi. org/10.2135/cropsci1971.0011183X001100060043x

JAMES, N.J.; MILLER, J.D. Selection in two seedling crops of four sugarcane progenies. Crop Science, v.11, p.245-248, 1971. http:// dx.doi.org/10.2135/cropsci1971.0011183X001100020023x

KIMBENG, C.A.; COX, M.C. Early generation selection of sugarcane families and clones in Australia: a review. Journal of the American Society of Sugar Cane Technologists, v.23, p.20-39, 2003.

LI, W.F.; FAN, Y.H.; CHEN, X.K.; XIA, H.M.; LI, F.Q.; WANG, Y.Y. Rapid determination method of cane sugar content. Sugar Crops of China, v.2, p.14-15, 2009.

LI, Y.P.; LI, S.J.; WU, J.X.; MENG, Z.Y.; GUO, F.Y. Application of DTOPSIS and grey relational analysis in evaluating newly introduced flue-cured tobacco varieties. Acta Tabacaria Sinica, v.18, p.35-40, 2012.

MA, W.Q.; GUO, Q.; LI, Y.; LI, H.R.; ZHU, R.; LUO, X.X.; LI, M.Z.; WEI, C.Z.; TANG, J.H.; QIU, W.W. Comprehensive evaluation of new sugarcane lines by DTOPSIS method. Sugar Crop of China, v. 1, p. 20-22, 2013.

MILLIGAN, S.B.; GRAVOIS, K.A.; BISCHOFF, K.P.; MARTIN, F.A. Crop effects on genetic relationship among sugarcane traits. Crop Science, v.30, p.927-931, 1990. http://dx.doi.org/10.2135/cropsci1 990.0011183X003000040034x
PAPINI-TERZI, F.S.; ROCHA, F.R.; VÊNCIO, R.Z.; FELIX, J.M.; BRANCO, D.S.; WACLAWOVSKY, A.J.; DELSHANTHI, R.M.; BHAGYALAKSHMI, K.V.; HEMAPRABHA, G.; NAGARAJAN, R. Relative performance of the sugarcane families in early selection stages. Sugar Tech, v.10, p.114-118, 2008. http://dx.doi.org/10.1007/ s12355-008-0019-8

SHEN, X.L.; DAI, H.J. Application of DTOPSIS in evaluation of new tomato varieties. China Vegetables, v.5, p.4-6, 2005.

STATISTIX. Analytical software. v8.0. Tallahassee. Disponível em: <http://www.statistix.com/>. Acesso: 6 maio 2014.

STRINGER, J.K.; COX, M.C.; ATKIN, F.C. Family selection improves the efficiency and effectiveness of selecting original seedlings and parents. Sugar Tech, v.13, p.36-41, 2011. http://dx.doi.org/10.1007/ s12355-011-0073-5

TAI, P.Y.P.; MILLER, J.D. Family performance at early stages of selection and frequency of superior clones from crosses among canal point cultivars of sugarcane. Journal American Society of Sugar Cane Technologists, v.9, p.62-70, 1989.

WELLS, W.C.; KOFOID, K.D. Selection indices to improve an intermating population of spring wheat. Crop Science, v.26, p.11041109, 1986. http://dx.doi.org/10.2135/cropsci1986.0011183X002 $600060003 x$

WU, C.W. The technique of sugarcane family selection of BSES in Australia. Sugarcane and Canesugar, v.1, p.6-9, 2007.

YAN, J.M.; HUANG, W.Z.; LV, Z.W.; LEI, S.F.; HUANG, C.Z. Study on the application of DTOPSIS comprehensive evaluation method in rice breeding. Journal of Anhui Agricultural Sciences, v.36, p.9428-9430, 2008.

YANG, L.H.; ZHAO, X.D.; BAI, Y.D.; LI, X.M.; LI, H.M. Integrated evaluation of sugarcane variety by DTOPSIS. Sugar Crops of China, v.1, p.40-43, 2014.

YAO, X.T.; ZHU, Y.D.; ZHANG, P.S. Method for multi-objectives evaluation on economics in rural area. System Sciences and Comprehensive Studies in Agriculture v.10, p.23-26, 1994.

YU, H.X.; YANG, L.H.; ZHOU, Q.M.; SUN, Y.F.; AN, R.D.; TAO, L.A.; DONG, L.H.; LANG, R.B.; FENG, W.; BIAN, X.; ZHU, J.R.; JING, Y.F. DTOPSIS evaluation of the eighth national sugarcane regional trail in Ruili site of Yunnan. Journal of Southern Agriculture, v.44, p.1613-1617, 2013.

ZHAO, P.F.; LIU, J.Y.; YANG, K.; XIA, H.M.; ZHAO, J.; LI, F.Q.; CHEN, X.K.; WU, C.W. Impact of staling on cane quality and sprouting, and the possibility of selecting for staling-resistant ability. International Sugar Journal, v.114, p.101-106, 2012.

ZHAO, P.F.; WU, C.W.; CHEN, X.K.; LIU, J.Y.; ZHAO, J.; YANG, H.C. Application of DTOPSIS on evaluating sugar cane lines. Sugar Crop of China, v.1, p.43-47, 2008.

ZHAO, P.F.; WU, C.W.; LIU, J.Y.; YANG, H.C.; ZHAO, J. DTOPSIS method for 7 chewing cane varieties. Sugarcane and Canesugar, v.1, p.10-12, 2007. 